\title{
1. 気管狭窄病態の基礎
}

*弓 削 庫 太

\section{Symposium: Treatment of Airway Stenosis}

\section{Experimental Study on Tracheostenosis}

\author{
Kurata Yuge, M.D. \\ Department of Otolaryngology, Nippon Medical School, Tokyo
}

Clinical cases of tracheal stenosis were investigated to study the cause of it. One hundred and eighty-two cases of tracheal stenosis were experienced (according to the data from the division of otorhinolaryngology of 37 universities) between January 1974 and July 1978. Of these cases, about $50 \%$ was caused by trachectomy and abcut $20 \%$ was caused by wounds, of which $60 \%$ was caused by traffic accidents.

In order to examine the vessels in the tracheas of rabbits, latex was injected into the aortas of 11 rabbits, and the following results were obtained. The tracheoesophageal arteries of rabbits are branched from right and left longitudinal trachecesophageal arteries (tentatively named). The right one is branched from the right subclavian artery and the left one from the left common carctid artery. There were some variations at the bifurcation of the left longitudinal trachecesophageal artery. The branches of the longitudinal tracheoesophageal arteries were ligated at 2 to 4 sites on each side of the right and left, but there was no change in the trachea. There were many vessels in the tracheal mucosa, and the anastomoses were very complicated. It was considered that there was no problem in hemodynamics in the cases of end-to-end anastomosis.

Curettage of tracheal mucosa, tracheotomy, intubation and crushing of trachea were conducted in rabbits and rats. Curettage of the whole circumference of tracheal mucosa did not result in stenosis. Regarding a cannula used for tracheotomy, its shape and size rather than its material are important factors for tracheal stenosis under the consideration of its fitness to the tracheal lumen. Using a tube with cuffs, inflammation of the trachea reaching to the perichondrium was already observed 10 hours after the intubaticn. When the cannula used was too large, necrosis and desquamation of the whole layers of muccsa, fcrmation of pseudomembrane and respiratory obstruction were observed, even though the application time was short. When tracheal cartilages of more than 3 arnuli were crushed, severe stenosis occurred. However, deformation and stenosis will be protected against to some degree if a T-tube, for example, is inserted in time into the crushed site.

\section{I ．緒言}

従来，気管狭窄の原因の大半は気管切開の合併症と して問題にされていた。しかし近年, 交通外傷に伴う

*日本医科大学耳鼻咽喉科学教室
喉頭及び気管外傷の増加及び全身麻酔，緊急の気道確 保の目的からの気管挿管等が新に気管狭窄の原因とし て注目されるに至り，それらの症例報告も年々増加の 傾向にある。

気管狭窄の症例に直面し，多くの外科医は様々な困 
表 1 気管狭窄の原因

(37 大学病院の集計)

\begin{tabular}{|c|c|c|c|c|c|c|}
\hline 原因別内訳 & S. 49 年 & 50年 & 51年 & 52年 & 53年 & 計 \\
\hline 外 傷 & 13 & 11 & 4 & 3 & 6 & 37 \\
\hline 気 管 切 開 & 16 & 12 & 19 & 14 & 19 & 80 \\
\hline Intubation & 5 & 5 & 6 & 3 & 3 & 22 \\
\hline $\begin{array}{l}\text { 先天性その他 } \\
\text { (Rerapsing } \\
\text { polychondritis) }\end{array}$ & 2 & 10 & 3 & 9 & 3 & 27 \\
\hline 計 & 36 & 38 & 32 & 39 & 31 & 166 \\
\hline
\end{tabular}

難な問題を克服して, その解決に大変な努力を払っ て，貴重な治験例を報告している。これら臨床成績を さらに向上させる点からも, 気管狭窄病態の基礎的問 題の研究は非常に重要と考える。

著者は気管狭窄病態解明の一助とす心゙く, 気管狭窄 症例の実態を調查し,つぎに気管の解剖（特に血管に ついて), さらに, 気管狭窄の動物実験を行った結果, 興味ある知見が得られたので報告する。

\section{II . 気管狭窄症例の実態調査}

気管狭窄の実態を把握する目的で, 全国大学附属病 院耳鼻咽喉科にアンケートを依頼した。

調査にあたって, 腫瘍による気管狭窄は除いて, 過 去 5 年間に年に何例気管管狭窄があったか，その原因 にはどの様なものが多かったか，治療についてはどの 様な方法を行っているか，またそれらの予後について も調查を行った。

昭和 49 年 1 月〜昭和 53 年 7 月迄の約 5 年間について の調査を依頼したが，別記の37校の耳鼻咽喉科から回 答を得た。

気管狭窄症例は合計 182 例で, 各年度每の気管狭窄 の内訳は表 1 の通りである。

気管狭窄の原因の中，気管切開によるものが $48.2 \%$ を占めているのが注目される。外傷は $22.3 \%$ ，先天 性, その他については relapsing polychondritis 3 例, laryngotracheomalasia 2 例, web 3 例, 喉頭了 ミロイド症 1 例があった。

気管狭窄症例の年令別内訳は表 2 に示す如く, 0 才〜 10才迄が79例 (43.4\%) の多くを占め, 21才〜 40 才，41才〜 60 才にもピークがみられた。また各年令層 において男性に多い傾向がみられた。

外傷による気管狭窄は交通外傷によるものが37例中 22例で，59.5\%を占めていた。
表 2 気管狭窄症例の年令別内䚿

\begin{tabular}{|c|c|c||c|}
\hline 年令 & $\hat{0}$ & ㅇ & 計 \\
\hline $0 \sim 10$ & 51 & 28 & 79 \\
\hline $11 \sim 20$ & 9 & 4 & 13 \\
\hline $21 \sim 40$ & 21 & 16 & 37 \\
\hline $41 \sim 60$ & 24 & 12 & 36 \\
\hline $61 \sim$ & 11 & 6 & 17 \\
\hline \hline 計 & 116 & 66 & 182 \\
\hline
\end{tabular}

表 3 気管切開より狭窄出現までの期間

\begin{tabular}{|c|c|}
\hline 1 週未満 & 5 \\
\hline 1 週 $~$ & ケ \\
\hline 1 ケ 月 $\sim 3$ ケ月 & 20 \\
\hline 3 ケ 月 $~$ & 23 \\
\hline 6 ケ 月 & 8 \\
\hline
\end{tabular}

表 4 Intubation による狭窄

a） 力フ使用の有無

\begin{tabular}{|c|c|c|c|c|}
\hline 使 & & & 用 & 16 \\
\hline 使 & 用 & せ & ず & 6 \\
\hline
\end{tabular}

b) Intubation の時間

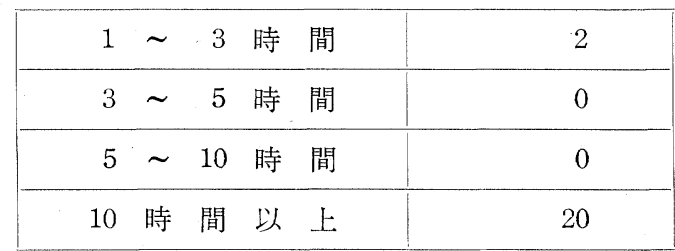

気管切開より狭窄出現までの期間は表 3 の如くであ る。気管切開後 3 ケ月迄に64例中 48 例 $(75 \%)$ に狭窄 の出現がみられた。

Intubation による狭窄は表 4 の如く，22例中カフ使 用16例 $(72.2 \%)$, intubation の時間は 10 時間以上の ものが90\%を占めていた。

以上アンケートの結果から, 気管狭窄の大部分は気 管切開, 気管外傷, 気管内插管後に発生していること が判った。

今回は気管切開の方法, カニューレの材質, カニュ ーレの適合性等について精細に調査を行わなかった 
が，気管切開後の気管狭窄が全体の約50\%を占めてい ることは注目に值する。

(このアンケートと別に 9 大学病院耳罳咽喉科での 気管切開例数を調查したが, 最近 5 ケ年に 637 例実施さ れており，その中に 1 例む気管狭窄を発生してない。）

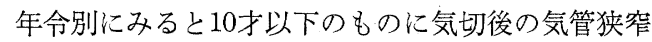
例が圧倒的に多く,このこと注従来の報告と一致する。

気切後 6 ケ月までに64例中 48 例 $(88 \%)$ が狭窄を起 しているので, 気切後約 6 ケ月間は慎重に経過を観察 する必要がある。

外傷後の気管狭窄の約 $60 \%$ は交通事故によるもの で，交通事故の患者で頸部損傷あるものに対しては， 特に気管損傷の有無を積極的に検索し，損傷ある場合 は早急に充分な処置を行うことが肝要である。

Intubation によるものは $90 \%$ が10時間以上の長時間 挿管したものであり，長時間挿管を余儀なくした患者
の経過観察にあたって，特に気管狭窄の有無を調べる ことを忘れてはならない。

アンケートの項目が少なく, 所期の目的を充分達し 得なかったが, この結果のみでも気管狭窄の今後の研 究に対し, 何等かの意義があったものと考える。

\section{III．気管の解剖（特に血管系について）}

気管の粘膜上皮についての研究は, 近年透過型, 走 査型電子䫓微鏡の発達により飛躍的な進歩をとげた。 しかし一方その血管系についての研究は非常に少な い。

気管腫湯切除後の気管吻合, 気管狭窄部位の切除後 の端々吻合, 気管内挿管後の気管狭窄の問題等, 実際 にそれら臨床にあたって，気管の解剖特に血管系につ いての解剖についての研究は有用であると考える。著 者は成熟家鬼を用いて，まず気管（食道）の血管につ
(1)

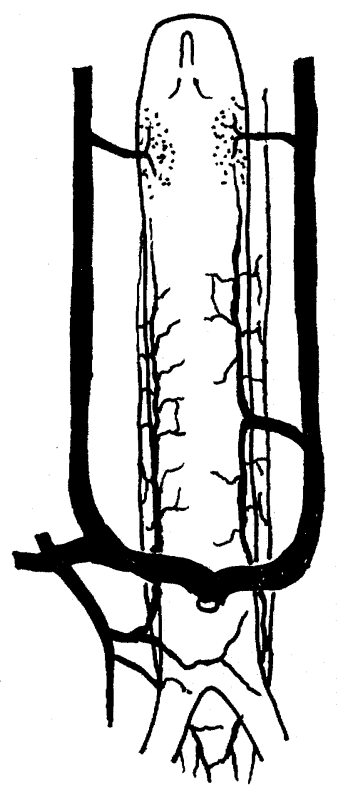

(2)

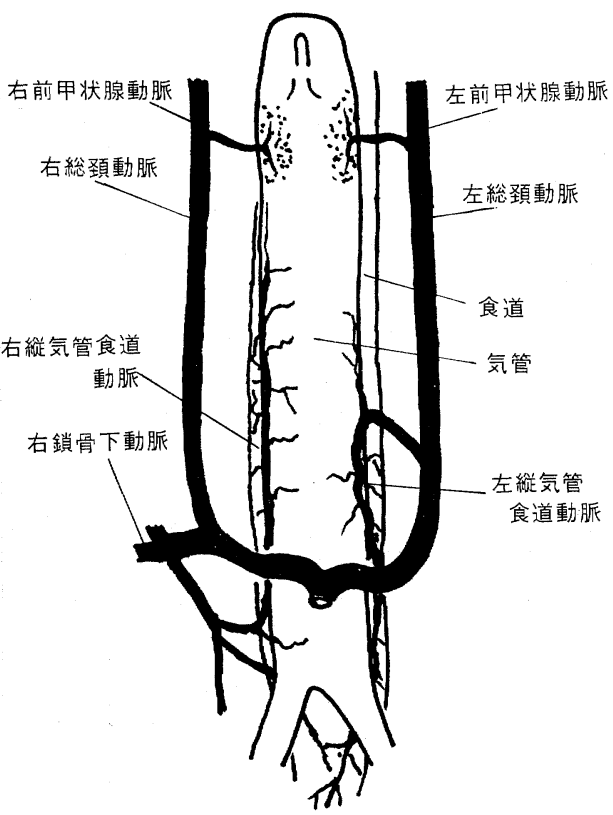

図 1 家鬼における気管食道脈分岐様式

(1) もっとも多いタイプ 右側：右鎖骨下動脈より分岐 左側：左総頸動脈より分岐

(2) (1) と似るが, 左縦気管食道動脈の走行が変っているタイプ 右側：右鎖骨下動脈より分岐 左側：左総頸動脈より分岐

(3) 特殊なタイプ（左総頸動脈より分岐しないもの） 右側：右鎖骨下動脈より分岐 左側：左喉頭動脈あるいは左上行咽頭動脈より分岐

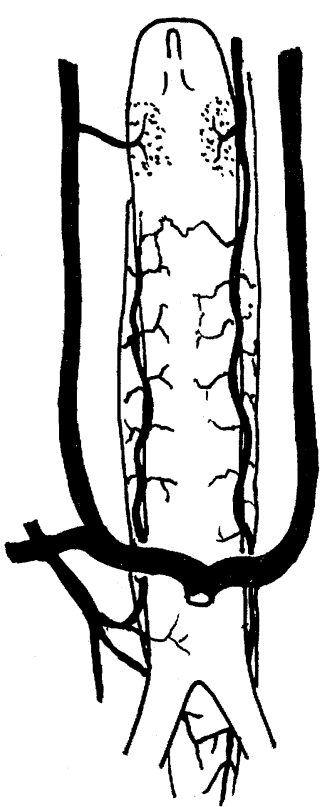


いて研究を行った。

1）研究方法。

エーテル麻酔下に開胸, 心臟を露出した後, 左心室 を切開し，あらかじめ血液を充分に流出させた後，大 動脈内にカテーテルを挿入し，ラテックスゴム（ネオ プレンラテックス $601 \mathrm{~A}$ ）を約 $15 \mathrm{cc}$ ，加圧して注入し た。胸大動脈はあらかじめ結禁し, 頭頸部領域にラテ ックスゴムの容易に流入するようにした。頭頸部領域 への流入の良否は眼球結膜等へのラテックスゴムの流 入の程度で判断した。

2) 研究結果

家鬼においては図 1 の如く，気管，食道の側面を左 右 1 本づつ縦走する動脈があり，これを著者は仮に縦 気管食道動脈と命名した。

この縦走する 2 本の動脈は分節状，樹枝状に気管及 び食道に細い分枝をだし，ところどころで，左右の縦 気管食道動脈は吻合していた。特に大動脈弓の高さよ り下部で吻合は多くみられた。

右側縦気管食道動脈は右鎖骨下動脈より分岐したも のであり，左側縦気管食道動脈は左総頸動脈より分岐 したものである。

左右共にこれらの動脈は上頸部で前甲状腺動脈より の枝としばしば吻合がみられた。これらの動脈は走 行，太さなど個体差が非常に大きい。

右鎖骨下動脈より分岐した血管は，大動脈弓の高さ よりやや下の位置で, さらに数本に分岐し，その内の 上行枝は気管，食道の側壁にそって，分節状，樹枝状 に細い枝をだしながら，上方へ走行していた。下行枝
は気管下部，下部食道，気管分岐部，気管支，肺胞へ と, 分節状, 樹枝状, 網状となって終っている。この実 験には11羽の家兔を用いたが，図 1 の(1)型が一般的 であった。なかには縦気管食道動脈の下行枝の内で, 気管の前面を右から左へ上，樹枝状に分岐しながら横 ぎり，左側の血管分枝との吻合がみられた。また下行 枝が気管後面を右から左へと横ぎって，左側の分枝と 吻合しているのがみられた。これらの走行, 左右吻合 の程度，血管の太さについての個体差は著しかった。

左総頸動脈より分岐した血管は, 気管, 食道の側面 に達すると，大きく上下に分れ，下行枝は，分節状， 樹枝状に枝をだしながら下行し，右側よりの分枝とと ころどころで吻合していた。また喉頭側へと進む上行 枝は同様に分枝をだしながら上行して，右側と同様に 前甲状腺動脈よりの枝としばしば吻合しているのがみ られた。左側縦気管食道動脈においても右側と同様に 分岐のしかた，走行，血管の太さなどにおいて個体差 がみられた。

特殊な例として, 図 1 の(3), 写真 1 の如く左側の血 管系で重要な役割をもつ左総頸動脈より分枝する血管 が欠除したものがあった。この様な事は家鬼など恝歯 類に比較的多いと云われている。この様な場合, 喉頭 動脈あるいは上行咽頭動脈より分岐した血管が縦気管 食道動脈となるものと考えられているが，著者は確認 できなかった。

写真 2 の如く, 縦気管食道動脈より分節状にでた細 い枝は，気管の表面をアーチ状に走り，様々な位置 (とくに 2 時, 10 時の位置) で, 気管壁内へ侵入して

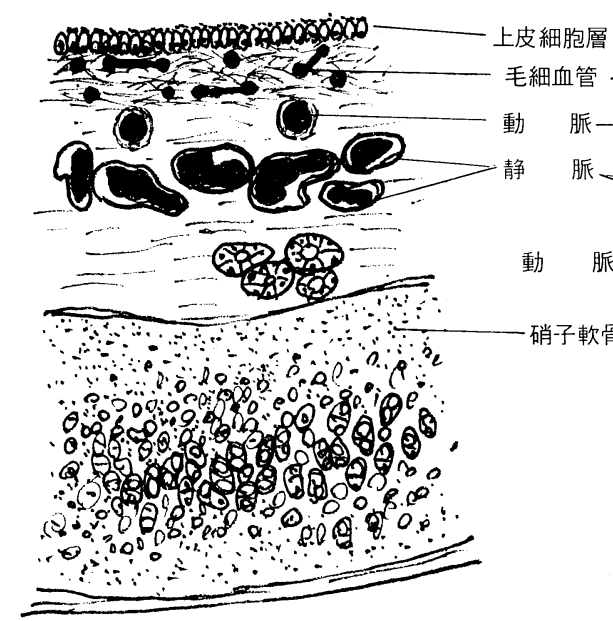

横断面

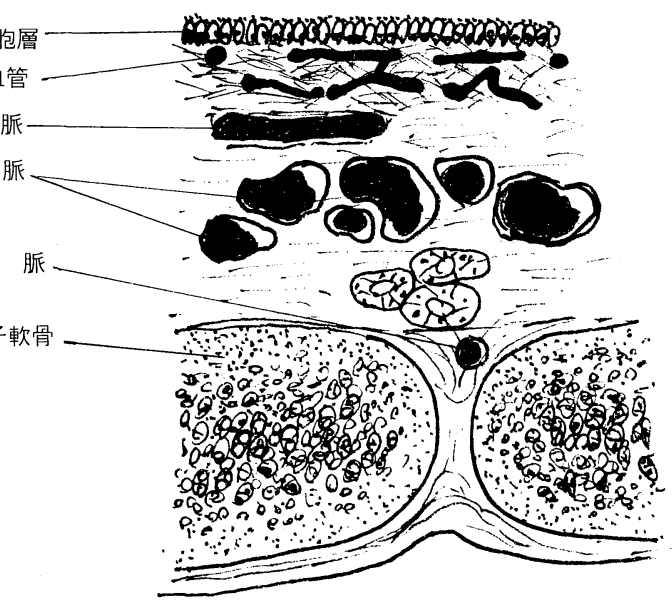

縦断面

図 2 家象気管における血管模式図（墨汁灌流標本より） 


\section{弓削庫太論文付図}

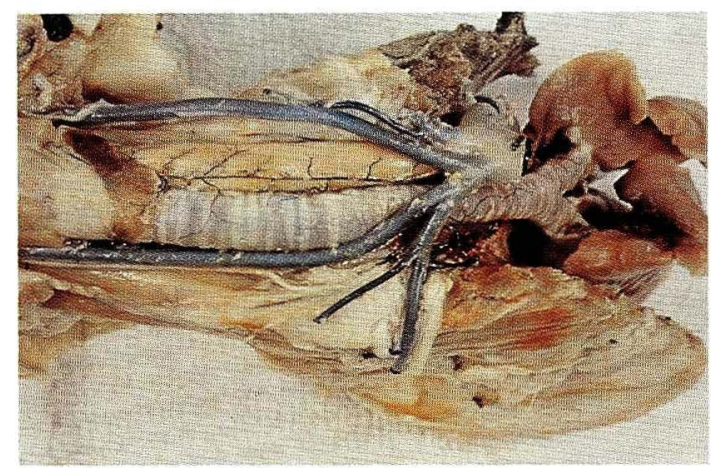

写真 I．家鬼ラテックスゴム注入標本

（図1の(3)にあたるもの）

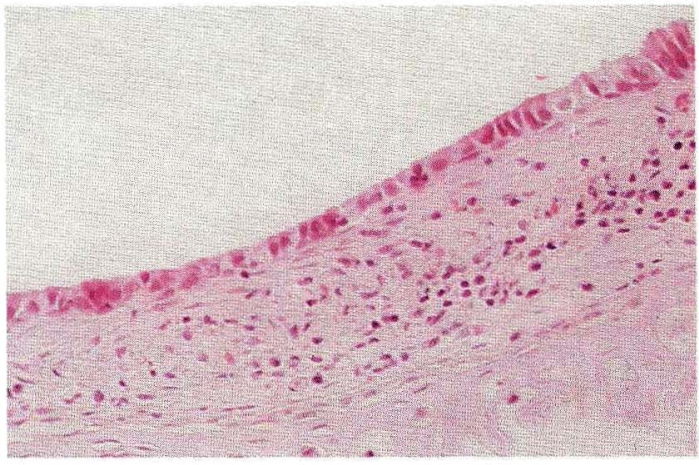

写真 3. (ラット) 粘膜上皮は、立方状で幼若である が、線毛細胞が明瞭である。固有層の炎症反 応は、すでに軽度である。

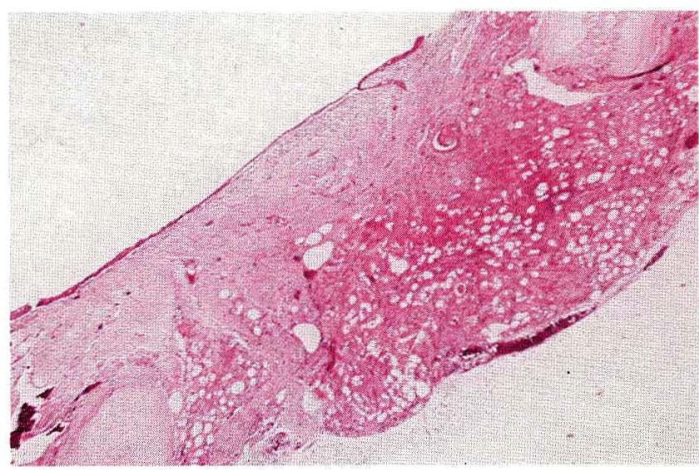

写真 5 .(家兔NNo.10）気管切開部は肉芽により閉鎖し、 瘏痕状となり、軟骨の壊死、変性はなく、新 生をみる。粘膜表層は再生上皮をみる。

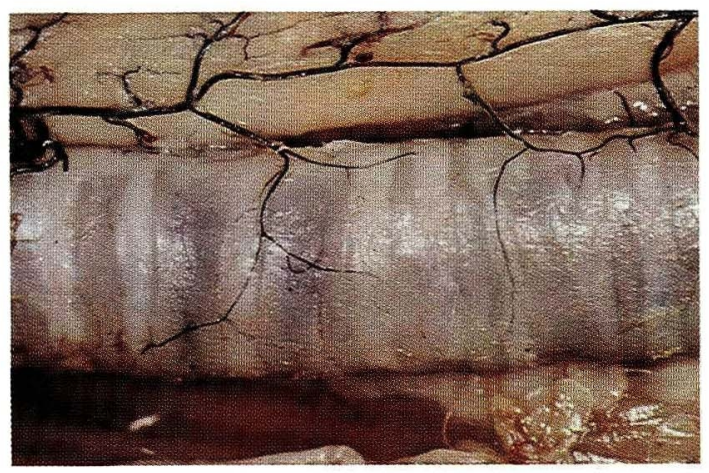

写真 2. 家鬼ラテックスゴム注入標本

（左縦気管食道動脈とその分節状の分岐）

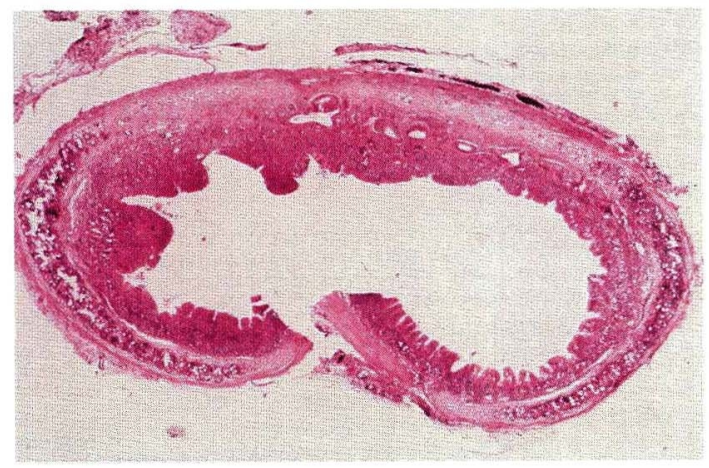

写真 4. (ラット) 2 回搔爬 7 日後の気管粘膜を示す。 粘膜は全体が肉芽状となり一部ではポリープ 形成をみる。

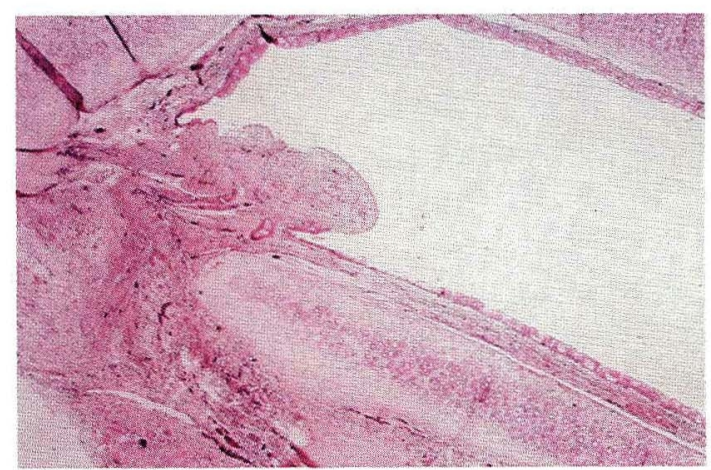

写真 6. (家兔№. 2) 気管切開部は肉芽により閉鎖し、 㓔痕状となっているが、一部は気管腔内にポ リープ状に突出している。軟骨の壊死、変性 はないが、軟骨の新生は明瞭でない。 


\section{弓削庫太論文付図}

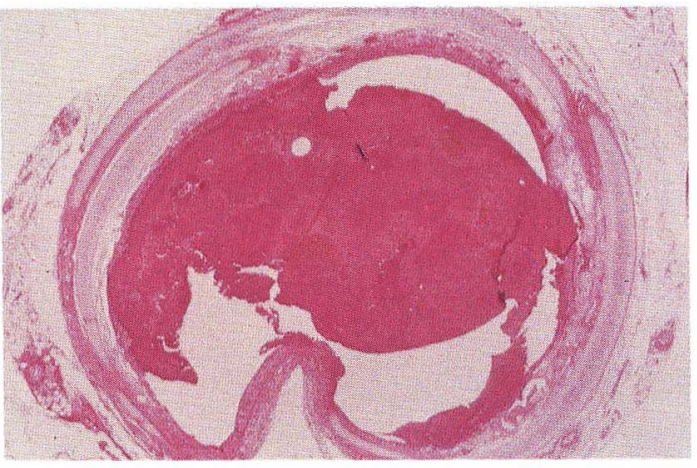

写真 7.(家鬼No. 5) 気管内腔は壊死組織により充満 している。粘膜は大部分の所で壊死、变性を 生じ、炎症は軟骨膜に達している。

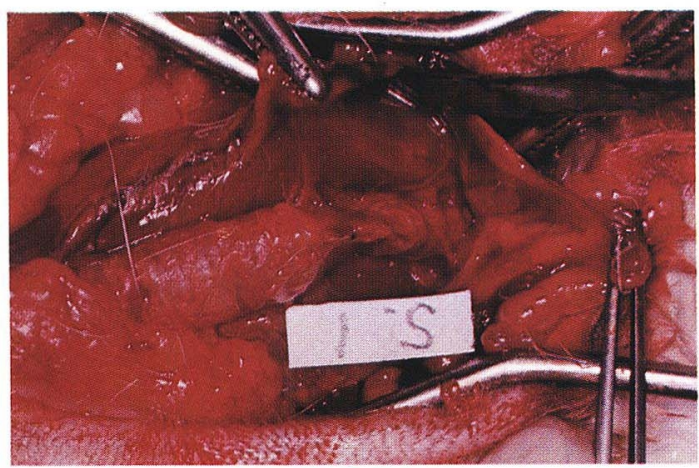

写真 9. (家兔NNo.6) 気管切開部の高度変形を示す (吸気時)。

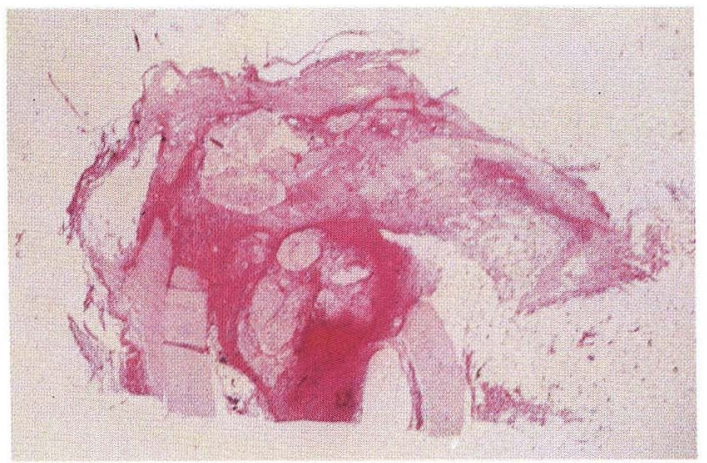

写真II. (家鬼N No.41) 軟骨輸は原形を止めず、内腔は 壊死組織と肉芽で充満し、破砕された軟骨片 は壊死、変性におちいっている。

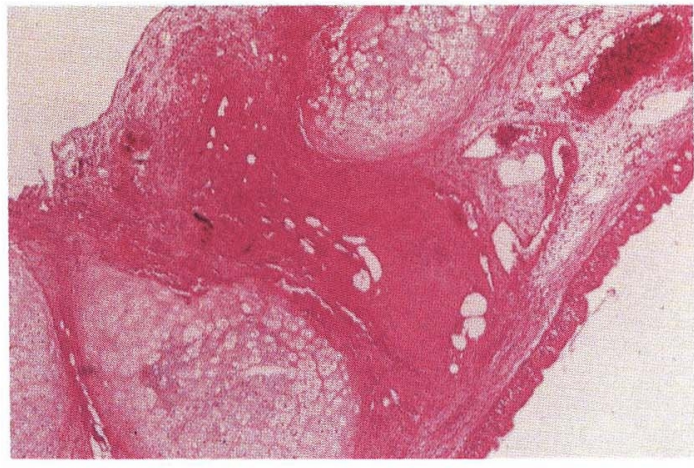

写真 8 . (家兔№.36) 軟骨輪には壊死、変性とその吸 収像がみられる。炎症反応はなお高度で、軟 骨間を通って粘膜上皮直下にまで及んでいる。

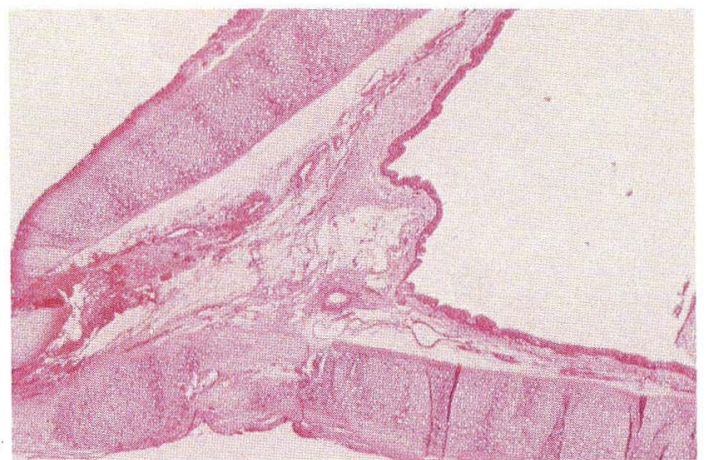

写真 10. (家鬼NNo.6) 写真 9 の組織像で、軟骨輪の変 形が著明である。軟骨の新生はみられるが、 離断部の癒合は立分で、粘膜の炎症反応はか なり消退している。

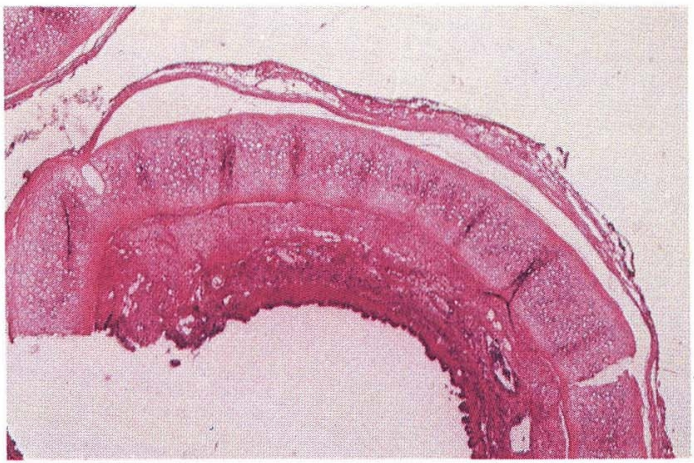

写真12. (家鬼NNo.48) 2 ヶ所に骨折を認めるが、軟骨 輪の変性はほとんどない。粘膜には高度の炎 症反応をみるが、壊死、変性はない。 
いくのをみとめた。アーチ状に走行する血管の走行 は，主に気管輪に一致しているが，あるものは，1〜 3 気管輪にまたがり, 斜めにまた縦に走って, 他のア 一チ状の枝と吻合したり，また反対側の枝との吻合も みられた。

一方気管内壁の血管系を追及するために，つぎの実 験を追加した。すなわち家鬼をエーテル全麻のもとに 開胸，左心室を切開し，体温に近く加温した $0.9 \%$ 生 理的食塩水を徐々に注入し，右心房を切開し，灌流食 塩水が血液を混じない様になったたところで，墨汁り ンゲル氏液（リンゲル氏液に墨汁 $15 \%$ ，ゼラチン 5 $7 \%$ 割合に混合したもの) を灌流せしめた後, 迅速 に頸部を氷塊にて冷却し注入液の凝固の促進をはかっ た。つぎにホルマリン固定後，適当な部分に切り出し て, 脱灰, 脱水後, ツェロイジン包埋し，20 30 $\mu$ の 連続切片を作製し，へマトシキリン，エオジン重染色 を行って観察した。その結果，図 2 の如く, 気管粘膜 の血管には，粘膜上皮直下に網状に毛細血管が分布 し，それより稍々外側に毛細血管網がみられる。これ らの血管網は 2 重構造性で, 縦走しているものが多く みられ，ところどころに吻合がみられた。これら毛細 血管網と気管軟骨及、゙輪状勒带との間の固有層に様々 な形態をとった，拡張した多数の静脈がみられた。一 方膜性壁部において，アーチ状に走行する動脈が多く みられた。気管粘膜層, 輪状勒帯内の血管の状態につ いては詳細な検討を要するが，想像以上に気管内壁は 血管が豊富であり，鼻腔に劣らない外気の湿度と温度 の調整作用を有するものと考える。

ヒトの気管，食道への動脈は屍体において検索した 結果は，教科書及び文献にあるごとく，それらへの動 脈は大動脈弓より鎖骨下動脈・甲状頸動脈・下甲状腺 動脈をへて気管・食道に至るもの，大動脈弓・胸大動 脈・気管支動脈を経て気管・食道に分布するもの，ま た鎖骨下動脈より最上肋間動脈をへて気管・食道へ分 枝するものがあった。家鬼にみられる様な縦気管食道 動脈はないが，それ以上に数多くの動脈から直接分枝 をらけており，当然のことながら家鬼より「ヒト」の 気管，食道の動脈分布状態は高級であった。

以上血管の研究結果から気管の端々吻合は合理的な 手術方法であり，積極的に実施してよいと考える。一 方, 粘膜上皮下には血管が非常に豊富であるので，肉 芽除去等の処置は慎重に行ら必要がある。

\section{IV．動物実験}

成熟家鬼及びラットを用いて，実験を行った。実験
方法によりつぎの 5 群に分けた。すなわち，気管粘膜 搔爬群，気管切開群，気管周囲電気焼灼群，気管挫滅 群，気管周囲血管結紮群に分けて実験を行った。

A）気管粘膜搔爬群

本実験は成熟ラットを用いて実施したが，気管粘膜 搔爬後の粘膜の修復について，また粘膜搔爬後狭窄を 来たすかを観察した。搔爬方法は従来の著者らの実験 方法に準じて気管全周に亘って充分搔爬を行った。

1 回搔爬群 (1 回搔爬後 3 ケ月まで経時的に観察), 2 回搔爬群（1回搔爬したものを， 1 週後再搔爬し て， 2 週後まで観察），及び 3 回搔爬群（2 回搔爬の ち 1 週後に再々搔爬を行ない，1 週後まで観察）の 3 実験を行い，それぞれについて光顕的，電顕的に観察 した。

実験結果：1回搔爬群では，搔爬 2 日後に多少のバ ラッキはあったが，創面全体が再生上皮により修復さ れ，間質には中等度の炎症反応をみるのみであった。

搔爬 1 週後には写真 3 に示すごとく, 再生上皮は多 列線毛上皮の形態を示す様になるが，基底細胞の増生 がまだみられ，間質にも炎症反応が残っていた。

搔爬 2 週後には粘膜上皮は分化した多列線毛上皮と なり，間質にも炎症所見はほとんど認めなかった。ラ ット約 500 匹の気管粘膜搔爬実験において, 術後 2 週 より約 3 ケ月にわたり, 精細に搔爬部位を病理組織学 的に検索したが，炎症が軟骨にまで波及し，気管の変 形及び狭窄，肉芽の発生などを来たすことはなかっ た。この事から気管粘膜上皮の再生，修復力の非常に 強いことがうかがわれた。

2 回搔爬群では, 写真 4 の如く, 1 週後には搔爬創 面の再生上皮による修復が終っているが，上皮は幼若 で, 間質は炎症反応が強く, 高度に肥厚し，一部肉芽 形成によりポリープ状を呈していた。2 週後，上皮は 多列線毛上皮となっていたが，な扔基底細胞の増生が みられ，間質の炎症反応は高度であった。

3 回搔爬群では, 1 週後に上皮の再生修復の遅れが 目立ち，ところどころに偽膜形成があり，創面は幼弱

表 5 気管粘膜搔爬実験

(ラット)

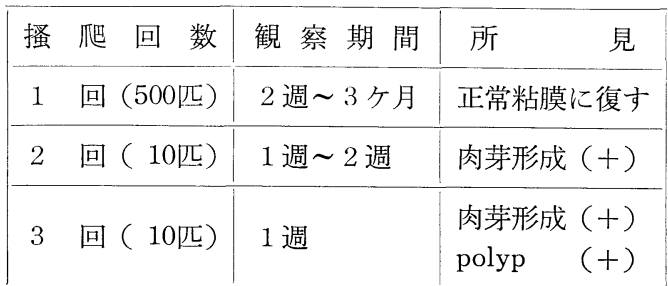


表 6 金属カニューレ使用群

(11例)

\begin{tabular}{|c|c|c|c|c|c|c|c|c|}
\hline \multirow{2}{*}{ No. } & \multicolumn{2}{|l|}{ 切 } & \multicolumn{2}{|c|}{$m=1-v$} & \multicolumn{2}{|r|}{ 所 } & \multicolumn{2}{|r|}{ 見 } \\
\hline & 位 & 方 法 & 捰入期間 & 抜去～気管摘出 & & 眼 & 狭 窄 & 組 \\
\hline 9 & 気 & 縦 & 5 日 & 17日 $(+)$ & & 塞 (壊死組織) & - & H \\
\hline 10 & $\prime \prime$ & 円 形 & 4日 & 10日 & & & - & H \\
\hline 11 & " & 円 形 & 16日 & 直 後 摘 出 & & & - & H \\
\hline 15 & " & 縦 & 27日 $(+)$ & . & 閉 & 塞（壊死組織） & - & H \\
\hline 32 & " & 縦 & 7日 & 直 後 摘 出 & & & - & H \\
\hline 12 & 輪 状 軟 骨 & 円 形 & 3日 & 14日 & 閉 & 塞（壊死組織） & - & H \\
\hline 17 & $\prime \prime$ & 縦 & 5 日 $(+)$ & 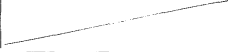 & 閉 & 塞（壊死組織） & - & H \\
\hline 21 & " & 縦 & 1日 & 7日 & & & - & H \\
\hline 22 & $\prime \prime$ & 縦 & 3 日 $(+)$ & 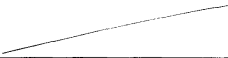 & & & - & + (肺炎) \\
\hline 23 & "1 & 縦 & 14日 $(+)$ & 直 後 摘 出 & & & - & $H$ \\
\hline 24 & " & 円 形 & 7日 & 直後摘 出 & & & - & $H$ \\
\hline
\end{tabular}

組織所見 （+）炎症が上皮に限局

（州）炎症が軟骨膜におよぶ
（十）炎症が固有層深層におよぶ

（州） 炎症が軟骨におよぶ
な再生上皮で被覆され，線毛細胞は僅かに散見される 程度であった。間質の炎症反応は 2 回搔爬群よりさら に強く, 創面全体が肉芽し，そのため管腔はやや狭小 となり，肉芽のなかには気管腔に大きくポリープ状に 突出しているのがみられた。

以上の実験結果から，1回だけの気管粘膜搔爬のみ では，短時間内に何等障害を残すことなく完全に修復 されることがわかった。しかしながら，搔爬を $2 ， 3$ 回と繰返すと, 粘膜の治療過程に障害を来し, 再生修 復が遅延し，間質の炎症はより高度となり，なかには 著明な肉芽の増生を生じ, 気管腔の狭小化を呈するも のがみられた。これらの所見は 1 回搔爬群では全くみ られなかった興味ある所見である。これら肉芽の増 生, ポリープの形成がその後, 徐々に消退して行くも のか，それとも更に軟骨膜，軟骨へと炎症が波及して 行くものかは，表 5 の如く実験例数が少く，長期間観 察してないので, 今後例数を増し，充分検討を加えな ければ断定できない。

B ) 気管切開群。

家兔（4 kg以上）19羽を用いて，第 4 第10気管輪 の間で， $3 \sim 4$ 個の軟骨輪を綐切開乃至円形の気管切 開を行い，図 3 のごときカニューレを使用した。気管 切開前にチオペンタールナトリウム $25 \mathrm{mg} \sim 50 \mathrm{mg}$ を静
注し，局所麻酔に $1 \%$ ) バカイン（1000×アドレナリ ン滴加）を使用した。カニューレを挿入後，カニュー レを絹系で皮膚に縫合して，抜去を防いだ。術後感染 予防には充分抗生剂を使用し，連日気道内分泌物吸引 を実施した。

(1) 金属カニューレ使用群

表 6 の如く，11例実験を行ったが，5例ににおいて 第 4 〜第10気管軟骨輪の間で切開を行い，6 例は輪状 軟骨を切開した。輪状軟骨を切断しないものは，経過 大概放良好であった。写真 5 は No.10 の気管切開口の 病理組織像である。著者の考案せる特製家鬼カニュー レを 4 日間挿入後に拔去して，その10日後に屠殺して 検索したものである。肉眼的に既に切開創は完全に閉 鎖されてあり，組織像で軽度の炎症所見がみられる が，切開創は結合織で関鎖され，気管内腔面は既に粘 膜上皮の再生修復がみられ，肉芽等形成なく，表面は 平滑で，軟骨の壊死はみられず，一部軟骨の新生がみ られた。他の同様の実験例においてもほぼ同様の所見 が得られた。

輪状軟骨におよぶ気管切開群はいずれも，術後感染 が高度のため膿瘍形成等が多くみられ，従って経過が 覀く，長期間観察が出来なかった。

(2) シリコン，テフロンカニューレ使用群 
表 7 シリコン, テフロン使用群

(8 例)

\begin{tabular}{|c|c|c|c|c|c|c|c|c|c|}
\hline \multirow{2}{*}{ No. } & \multicolumn{2}{|c|}{ 切 } & \multicolumn{2}{|c|}{ 開 } & 大 & $=$ & $-\quad v$ & \multicolumn{2}{|r|}{ 見 } \\
\hline & 部 & 位 & 方 & 法 & 大 小 & 挿 入期間 & 抜去～気管摘出 & 肉 & 組 織 \\
\hline 1 & 気 & 管 & & & 中 & 12時間 (十) & & 閉 塞（壊死組織） & H \\
\hline 2 & & " & & & 中 & 5 日 & 17 日 & & H \\
\hline 3 & & " & & & 中 & 3日 $(+)$ & & 閉 塞（壊死組織） & H \\
\hline 5 & & " & & & 大 & 24 時間 $(+)$ & & 閉 塞 (壊死組織) & $H$ \\
\hline 6 & & " & & & 大 & 2日 & 4 ケ月 & 狭 窄 著 明 & H \\
\hline 7 & & " & & & 大 & 24時間 $(+)$ & & 閉 塞 (壊死組織) & H \\
\hline 8 & & " & & 形 & 中 & 17時間(+) & & 閉 塞 (壊死組織) & H \\
\hline 39 & & " & & & 大 & 2 日 & 直 後 摘 出 & & H \\
\hline
\end{tabular}

表 8 力フ付チニーブ使用群

(12例)

\begin{tabular}{|c|c|c|c|c|c|c|c|c|c|}
\hline \multirow{2}{*}{ No. } & \multirow{2}{*}{ 切 } & \multirow{2}{*}{ 開 } & \multirow{2}{*}{ 部 } & \multirow{2}{*}{ 位 } & \multirow{2}{*}{$\begin{array}{c}\text { 力 フ 付 } \\
\text { 挿 入 期 間 }\end{array}$} & \multirow{2}{*}{$\begin{array}{l}\text { チューブ } \\
\text { 抜去〜気管摘出 }\end{array}$} & \multicolumn{2}{|r|}{ 所 } & 見 \\
\hline & & & & & & & 肉 & 眼 & 組 織 \\
\hline 13 & 気 & & & 管 & 48時間 & 14 日 & & & $H$ \\
\hline 14 & & & & & 24時間 & 30 日 & & & H \\
\hline 16 & & & & & 48時間 & 7 日 & & & $H$ \\
\hline 18 & & & & & 24時間（十） & & 壊 & 死 組 織 & H \\
\hline 19 & & & & & 24時間（十） & & 壊 & 死 組 織 & H \\
\hline 20 & & & & & 24時間（十） & & 壊 & 死 組 織 & H \\
\hline 25 & & & & & 48時間 & 2 日 & & & H \\
\hline 29 & & & & & 24時間 & 7 日 & & & $H$ \\
\hline 31 & & & & & 48時間（十） & & 壊 & 死 組 織 & H \\
\hline 38 & & & & & 10時間 & 2 日 & & & H \\
\hline 37 & 甲状 & 骨と & 状軟 & の間 & 72時間 （+） & & 壊 & 死 組 織 & H \\
\hline 40 & 甲 & 状 & 軟 & 骨 & 24時間 (+) & & 壊 & 死 組 織 & $H$ \\
\hline
\end{tabular}

家鬼（4 kg以上） 8 羽を用い，第 4 第10気管軟骨 を中心に形成され，気管分岐側へのびているのがみら 輪の間で気管切開を行い，乳幼児用のシリコン又はテれた。No. 5 はシリコンカニューレを無理に挿入した フロン製カニューレ使用した。

表 8 に示すごとく, No. 1, No. 5 , No. 7 , No. 8 の 4 羽はシリコンカニューレを挿入後 $12 \sim 24$ 時間後に死 亡した。いずれも原因は壊死組織の気管腔閉塞に因る むのであった。壊死組織はすべて, カニューレの先端 例で，24時間後に死亡したもの。写真 7 はその組織所 見を示す。気管粘膜の壞死脱落, 壊死組織の気管腔閉 塞がみられる。

気管切開孔周辺の軟骨膜及び軟骨に一部壊死変性が みられた。 
シリコンカニューレで適性なもの を使用すると, No. 2 の如く, 写真 6 に示すごとく順調な経過をとった。

No. 6 汇気管切開後, かなり太目 のシリコンカニューレを無理に挿入 したもので, 術後 2 日目に呼吸困離 を認めたため，カニューレを抜去 し，そのまま約 4 ケ月間生存させた が，吸気時に喘鳴が著明に現われた ので，直ちに局麻下に頸部を開い て，気管切開部を検索した。写真 9 に示すごとく, 気切部の 4 輪にわた って，気管に著明な変形が認められ た。狭窄部が呼吸と共に膨脹, 収縮 するのが認められ，吸気時に著明な 狭窄がみられた。

組織学的にみると, 写真10に示す ごとく, 気切部は高度に変形し, 気 管内腔は狭小となり，粘膜上皮には 特に異常はなかったが, 固有層は肥 厚し, 瘯痕状で中等度の細胞浸潤が みられた。また軟骨輪の一部に壊死 破壊像がみられた。この例が気管切 開実験における唯一の気管狭窄例で あり。気管カニューレの適合性の重 要さを一層痛感した。

(3) カフ付チューブ使用群

家鬼（4kg以上）12羽を用い，第 4 〜第10気管輪の間で気管切開し, 著者の考案せる図 3 に示すカフ付シ リコンチューブを切開孔から挿入し た。カフを充分にふくらませ, 気管 壁の膨隆するのを確かめて, カフ付 チューブを気管壁に固定した。最も 長時間のもので，72時閒チューブを 留置し, またカフ付チューブ抜去後 長いもので30日まで生存させて観察 した。

No. 18 , No. 19 , No. 20 , No. 31 , No. 37, No. 40の 6 例はカフ付チュ ーブ留置のまま, 気管腔内壊死組織 閉塞のため死亡した。

組織学的にはチューブ㨂入部に粘 膜の壊死, 軟骨膜に達する高度の炎 症がみられた。カフ付チューブ留置

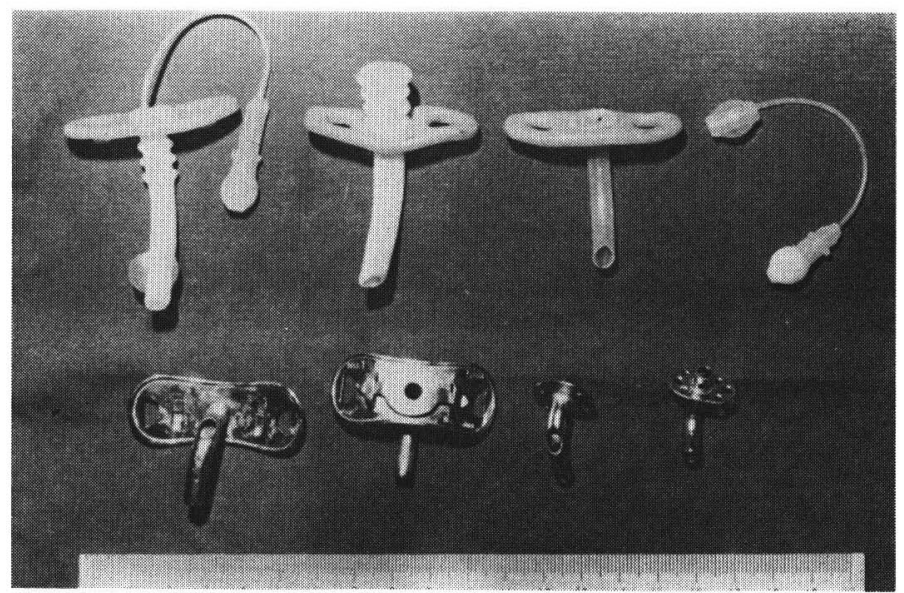

図 3 小児用カニューレ（シリコンカフ付, シリコン，テフロン）， 特製シリコンカフ付チューブ, 小児用 No. 1 金属カニューレ 2 個 (先端一部切断), 特製家鬼用カニューレ（2 個）

表 9 気管周囲電気 焼灼群

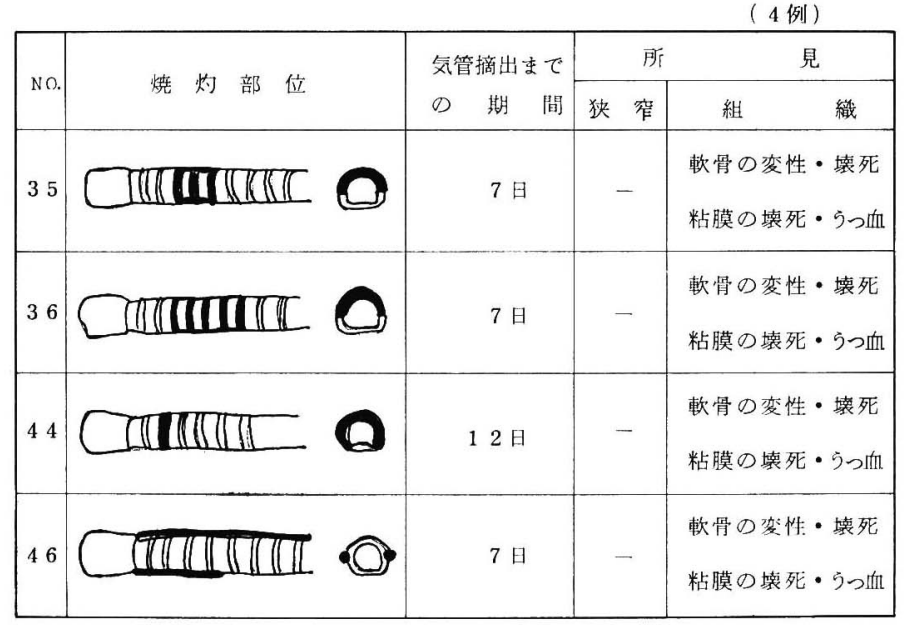

表10 気 管 挫 滅 群

(4 例)

\begin{tabular}{|c|c|c|c|c|c|c|c|c|c|}
\hline \multirow{2}{*}{ No. } & \multirow{2}{*}{\multicolumn{2}{|c|}{ 挫滅気管輪の数 }} & \multirow{2}{*}{ Tチューブ } & \multirow{2}{*}{\multicolumn{2}{|c|}{ 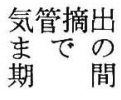 }} & \multicolumn{2}{|c|}{ 所 } & \multicolumn{2}{|r|}{ 見 } \\
\hline & & & & & & & 窄 & 組 & 織 \\
\hline 41 & 3 & 本 & 使用 せず & 2 & 日 & 著 & 明 & & H \\
\hline 43 & 2 & 本 & 挫隇部に插入 & 2 & $\mathrm{H}$ & & - & & W \\
\hline 47 & 1 & 本 & "I & 5 & 日 & & - & & W \\
\hline 48 & 4 & 本 & $\prime \prime$ & 2 & 日 & & & & W \\
\hline
\end{tabular}




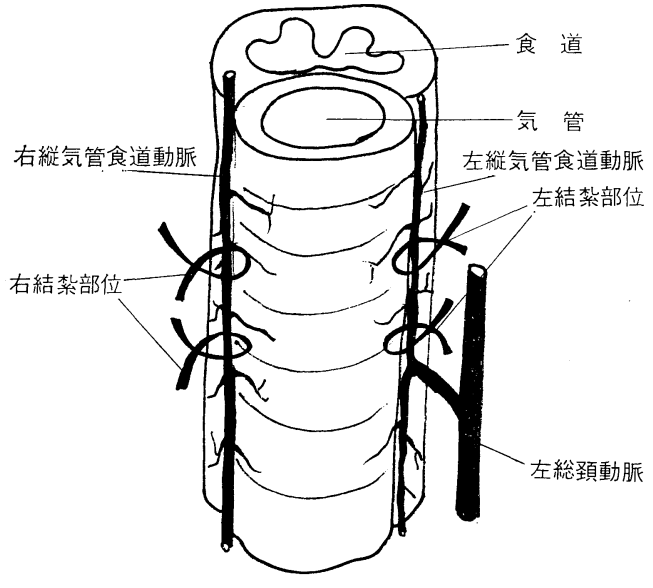

図 4 気管周囲動脈結紮実験法

部より気管分岐側へ壊死組織が生じていたが，シリコ ンカニューレ群より範囲は狭く, 限局性であった。シ リコンカニューレ使用群と同様，気管内壁の過度の圧 迫による粘膜内血管の循環障害によるものと考えられ る。

No. 13 , No. 14 , No. 16 , No. 25 , No. 29 , No. 38 の 6 例には中等度の炎症所見しかみられなかったが， カフの空気もれのため，充分気管壁を圧迫できなかっ たためと考える。

C ）気管周囲電気焼灼群

気管周囲の障害が気管内腔へ波及するか，また気管 軟骨破壊による気管狭窄を想定して，気管周囲の電気 焼灼実験を行った（ 9 表）。

No. 36 は気管輪を 5 個, 充分に電気焼灼を行った。 写真 8,12 に示す如く, 軟骨膜, 軟骨に炎症が波及 し，軟骨間の輪状䩲帯から，気管粘膜固有層に及ぶ高 度の炎症がみられた。また血管に栓塞がみられた。

D) 気管挫滅群

比較的下位（第 8 第13気管輪の間）で気管切開を 行い，切開口と輪状軟骨の中間で，気管輪を $1 \sim 4$ 個 の軟骨輪を鋭匙鉗子で強くはさんで挫滅した。

表10に示す, No. 41 の 3 輪を挫隇した 1 例をのぞ

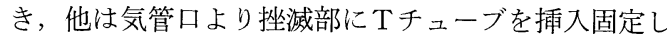
た。

No. 41，No. 43，No.48はそれぞれ 2 日後に屍殺し た。No. 47は 5 日後に屍殺した。

No. 41はTチューブを使用しなかった例で，外見的 に挫滅部位の気管に著明な狭窄がみられた。内腔は全 く閉鎖し，肉芽が充満していた。

組織学的には写真11に示す如く，壊死組織と肉芽が
充満し，肉芽内に軟骨片が埋没しているのがみられ た。気管輪は原形をとどめることなく多数の軟骨片と して散在し，壊死，変性が著明であった。

No. 41, No. 43, No. 48の 3 例はいずれも Tチュー ブを使用したものである。いずれも気管の変形はみら れなかった。

組織学的には写真12に示す如く, 粘膜には高度の炎 症反応がみられるが, 固有層は肥厚し, 浮腫, 出血, 細胞浸潤が著明で肉芽状であったが，壊死，変性はみ られなかった。軟骨膜には中等度の細胞浸潤をみた。 気管輪には多数の骨折を認め, 一部に変性がみられた が，軟骨骨折部の離開は軽度で，ほぼ軟骨輪の形態が 保持されていた。

Tチューブ使用例では軟骨輪の 変 位, 変形が軽度 で，粘膜にはなお高度の炎症反応がみられたが壊死， 変性はみられなかった。

以上の結果から，気管外傷の新鮮例において，受傷 部位を切除して，端々吻合を直ちに実施することな く，障害の程度によっては，Tチューブ等をまず使用 して, 気管輪のつぶれを整復して, 気管狭窄の防止を はかってもよい様に思う。また Tチューブ等の使用期 間等は今後の研究課題である。

E）気管周囲血管結杽例

4 例において，気管周囲動脈を双眼顕微鏡下に図 4 の如く動脈結禁実験を行った。しかし 1 例も気管組織 に異常所見を得ることができなかった。このことから 気管血管系の複雑性がうかがわれる。しかし一方気管 壁よりの出血は止血困難であることを示唆するもので ある。

\section{$\mathrm{V}$ ま と め}

1. 気管粘膜搔爬群において，1回搔爬では気管狭 窄は全く起らなかった。反復搔爬では著明な肉芽・ polyp 形成を来したものがあった。

2. カニューレ使用群において，カニューレの材質 よりも, カニューレの太さや形の気管腔との適合性の 方が，気管狭窄の重要な因子と考えられた。

3. カフ付カニューレ群において，10時間後に，す でに軟骨膜に及ぶ炎症性変化がみられた。

4. カニューレの太すぎる場合には, 短時間でも, 粘膜全層の壊死・脱落・偽膜形成を生じ, 内腔の閉塞 するものがあった。

5. 気管周囲焼灼群において, 焼灼部位に一致した 気管内側粘膜面に循環障害による高度の炎症の出現が みられた。 
6. 気管挫滅群において，挫滅が軟骨 3 輪以上とな ると高度の狭窄を生じた。ただし挫滅部位に早期に T チューブを使用することにより, 変形・狭窄を防止し 得るものと考えた。

気管狭窄臨床例につき，アンケートに御協力いただ いた下記大学耳鼻咽喉科に深謝します。

北海道大学, 札幌医科大学, 弘前大学, 秋田大学, 東北大学, 福島大学, 自治医科大学, 独協医科大学, 埼玉医科大学, 防衛医科大学, 千葉大学, 東京大学, 東京医科大学, 東邦大学, 横浜市立大学, 聖マリアン 十医科大学, 北里大学, 新潟大学, 信州大学, 金沢医 科大学, 岐阜大学, 名古屋大学, 三重大学, 奈良県立 医科大学, 京都府立医科大大学, 大阪大学, 大阪市立 大学, 兵庫医科大学, 岡山大学, 川崎医科大学, 福岡 大学, 長崎大学, 宮崎医科大学, 琉球大学。

なお差出人不明の 2 校がありました。

終りに本シンポジウムの機会を与えて下さった梅田 良三会長，司会の広戸幾一郎教授に感謝します。合せ て長年にわたって御指導を頂いた大藤敏三名誉教授, 橋本泰彦名誉教授, 永井汇教授並に解剖学教室吉川文 雄教授, 病理学教室福士勝成教授に感謝します。なお 本研究に御協力いただいた教室員各位及び物心ともに 御教授いただいた橘鏡会々員，四五会々員の方々に感 謝します。

\section{文献}

1 ）広戸幾一郎：喉頭外傷の治療, 耳展, 8：10, 1965.

2 ）切替一郎, 他: 喉頭 - 頸部気管狭窄 $の$ 手術 的療 法，日気食会報，20：18-27，1969.

3 ）斉藤紘昭：ヒトの頸部，上胸部気管・食道動脈の 解析, 解剖学雑誌, 51：409-421, 1976.

4 ) 広戸幾一郎：喉頭気管狭 窄 の治療, 耳鼻, 22 : 679-687, 1976.

5 ) Salassa, J.R., Pearson, B.W. and Payne, W.S.: Gross and microscopical blood supply of the trachea. The Annals of Thoracic Surgery, 24 : 100-107, 1977.

6 ) Nordin, U. and Lindholm, C.E.: The vessels of rabbit trachea and ischemia caused by cuff pressure. Arch. Otorhinolaryngol., 215 : 11-24, 1977.

7 ) Nordin, U.: The trachea and cuff-induced tracheal injury, Acta Otolaryngol., supplement 345, 1977.

8 ) 佐藤武男：喉頭・気管狭窄の実態とその治療, 耳 鼻, $24: 419-426,1978$.

9 ）石原恒夫：気管 - 気管支成形術の臨床, 日胸, $37: 433-438,1978$.

10) 弓削庫太・他：搔爬気管粘膜の修復に関する電 顕, 並びにオートラジオグラフィーによる観察, 耳 展, 21，(補 2 ）：109-125, 1978.

11）金子丑之助：日本人体解剖学, 第三巻, 南山堂, 1972 .

(別刷請求： T102 東京都千代田区飯田橋 3-5-5 日本医科大学附属第一病院耳鼻咽喉科 